\title{
Zinc-Induced Genotoxic Effects in Root Meristems of Barley Seedlings
}

\author{
Elena C. TRUTA ${ }^{* *}$, Daniela N. GHERGHEL', Iulia Csilla I. BARA², Gabriela V.VOCHITA' \\ ${ }^{1}$ Institute of Biological Research Iasi branch of NIRDBS, Department of Applied and Experimental Biology, 47 \\ Lascar Catargi Street, 700107 Iasi, Romania; trutaelena@yahoo.com ("corresponding author) \\ ${ }^{2}$ Alexandru Ioan Cuza University, Faculty of Biology, 20 A Carol I Blvd., 700506 Iasi, Romania
}

\begin{abstract}
The pollution increase, as a result of the release into environment of genotoxic chemicals, including heavy metals, largely affects the ecosystems and the health of living organisms. Although zinc is not considered highly phytotoxic, its excess becomes noxious. In literature, the reports on zinc genotoxicity are equivocal. Therefore, the objective of this work was to evaluate the amplitude of cytogenetic damage induced in Hordeum vulgare L. cv. 'Madalin' after seed treatment with different concentrations $(10,100,250,500 \mu \mathrm{M})$ of $\mathrm{Zn}^{+2}$, provided as zinc sulphate and zinc acetate. The mitostimulatory effect was present at all concentrations of both zinc compounds. The rate of ana-telophase aberrations exceeded by 2 - 3 times the control, and the frequency of metaphase disturbances was 5.0-10.0 times higher than the control. The results indicate the clastogenic and aneugenic potential of zinc in barley and constitute a signal about the risks of its increasing presence into the environment, with repercussions on living systems, even on human health, due to the extensive use of zinc compounds including as pesticides.
\end{abstract}

Keywords: aneugenic effect, chromosome aberrations, clastogenic action, heavy metals

\section{Introduction}

In addition to its undeniable positive effects, the progress of human society had disastrous repercussions on biological systems due to the increase of the pollution level. Chemical pollution by heavy metals resulting from anthropogenic or natural sources is only one of the factors enhancing the risks for the environment and living organisms because they tend to accumulate in soil, water and plant and animal tissues. Despite the measures taken in many countries to counteract their release into the environment, this phenomenon has been continuously increasing. In Romania, in 2004, of the 0.9 million chemically polluted ha, 0.2 million ha were excessively contaminated with heavy metals that exceeded the maximum allowable limits (3 - 30 times for $\mathrm{Pb}, 2$ - 32 times for $\mathrm{Cd}, 2$ - 3 times for $\mathrm{Zn}, 2-4$ times for $\mathrm{Cu}$ ); high amounts were detected in plant leaves (Sanitation Country Profile, 2004).

Zinc is an essential nutrient for living organisms, representing the $23^{\text {rd }}$ most abundant element on earth (Broadley et al., 2007) and the $2^{\text {nd }}$ most abundant transition metal, after iron (Jain et al., 2010). Environmental $\mathrm{Zn}$ accumulation is due to mining and refining of nonferrous metals, chemical industry, burning of fossil fuels, and agricultural utilization of fertilizers and herbicides $(\mathrm{Zn}$ chloride and $\mathrm{Zn}$ sulphate) (Päivöke, 2003). The total $\mathrm{Zn}$ content of soils varies between 10 and $300 \mu \mathrm{g} / \mathrm{g}$ (Tewari et al., 2008), or from 4 to $270 \mu \mathrm{g} / \mathrm{L}$, in soil solutions, with a maximum of $17,000 \mu \mathrm{g} / \mathrm{L}$ in the highly contaminated soils (Kabata-Pendias and Pendias, 2001). Zn is redox-stable under physiological conditions, being considered as one of the least toxic heavy metals (Codina et al., 2000; Steinkellner $e t$ al., 1998). It is a structural stabilizing factor of cell membrane and DNA-linking proteins (Salama and El Fouly, 2008) and it plays a significant role in the control of gene expression and DNA transcription (Päivöke, 2003). $\mathrm{Zn}$ excess becomes toxic to plants by altering the physiological processes (Jain et al., 2010). The toxicity limits for $\mathrm{Zn}$ depend on plant species, genotype, and growth stage. Hence, about $300 \mathrm{ppm} \mathrm{Zn}$ is reported to be toxic to young barley (Davis et al., 1978). Most commonly, the upper toxic levels range between 100 and $500 \mathrm{ppm}$ (Macnicol and Beckett, 1985), whereas Paschke et al. (2006) emphasized that $\mathrm{EC}_{50}$ varies between 43 and $996 \mathrm{mg} \mathrm{Zn/L}$.

As $\mathrm{Zn}$ forms stable complexes with nucleic acids, it can negatively influence their stability, so producing errors in the genetic information system (Patra et al., 2004). The evaluation of the genotoxic impact of xenobiotics by investigating the extent of chromosome damage represents an effective method for biomonitoring studies. The interaction between $\mathrm{Zn}$ and DNA is little known in the light of its involvement in carcinogenesis. The studies on $\mathrm{Zn}$ genotoxicity and mutagenicity conducted in a variety of test systems resulted in non convincing results. Therefore, chromosomal aberrations, single-strand breaks or SCEs have been observed in rats and mice following in vivo exposure to Zn (Banu et al., 2001; Kowalska-Wochna et al., 1988), but there was no convincing evidence on the clastogenic effect in human lymphocytes exposed to $\mathrm{Zn}$ chloride (Deknudt and Deminatti, 1978). Also, Zn acetate did not 
show mutagenic activity in Salmonella assays, but induced positive responses in in vitro cytogenetic $\mathrm{CHO}$ assay (Thompson et al., 1989) and in Vicia faba micronucleus assay (Kumari et al., 2012).

The continuous production and release of chemicals into the environment emphasize the necessity to assess their genotoxicity. Plants, which constitute a main link in the food chain, are often used to evaluate the genotoxic and mutagen potential of risk factors, due to the highly preserved structure of their genetic material. Barley is a plant of worldwide economic importance, which also has cancer preventive properties due to lunasin, a recently discovered peptide (Lumen, 2008). It has 14 large chromosomes and is often used as monitoring system in the evaluation of possible genetic risks of heavy metals.

The main purpose of this paper is to evaluate the genotoxic potential of $\mathrm{Zn}$ (provided as $\mathrm{Zn}$ sulphate and $\mathrm{Zn}$ acetate), expressed as chromosomal damage and mitotic irregularities, by analyzing the clastogenic and aneugenic effects induced in root meristems of barley seedlings.

\section{Materials and methods}

Seeds of early, autumn, six-row Hordeum vulgare L. cv. 'Madalin' provided by the Center for Agricultural Research and Development from Secuieni were used. This Romanian commercial variety having the grain yield potential over $6000 \mathrm{~kg} \mathrm{ha}^{-1}(1000$-seed weight $=42-45 \mathrm{~g}$ ) was created at National Institute of Agricultural Research and Development - Fundulea (Patent 111732 B1 - 1994).

The barley grains were $3 \mathrm{~min}$ surface sterilized with freshly prepared solution of $2 \% \mathrm{NaOCl}$, operation followed by several washes to remove any trace of disinfectant. The seeds were then subjected for 3 hours to the treatment with solutions of $10,100,250$, and $500 \mu \mathrm{M} \mathrm{ZnSO}_{4} .7 \mathrm{H}_{2} \mathrm{O}$ $(\mathrm{MW}=287.5799 \mathrm{~g} / \mathrm{mol})$ and $\left(\mathrm{CH}_{3} \mathrm{COO}\right)_{2} \mathrm{Zn}_{2} 2 \mathrm{H}_{2} \mathrm{O}$ $(\mathrm{MW}=219.5286 \mathrm{~g} / \mathrm{mol})$ containing $0.654,6.54,16.35$, and $32.70 \mu \mathrm{g} \mathrm{ml}^{-1} \mathrm{Zn}^{2+}$, respectively. Controls were free from any heavy metal. After chromium treatment and several rinses with running tap water, the seeds were transferred on moistened filter paper, in order to germinate. Petri dishes were covered and incubated in dark at $20^{\circ} \mathrm{C}$.

For cytogenetic analysis, barley roots $(10-15 \mathrm{~mm}$ in length) were fixed for $24 \mathrm{~h}$ in ethyl alcohol:glacial acetic acid $(3: 1, v / v)$, at room temperature, then washed and stored in $70 \%$ ethyl alcohol. The plant material was hydrolyzed for 10 minutes in $50 \% \mathrm{HCl}$, and then stained in modified charbol fuchsin $\left(24\right.$ hours, at $+4^{\circ} \mathrm{C}$ (Gamborg and Wetter, 1975). To prepare the slides (five per variant) - the meristematic regions were squashed into $45 \%$ acetic acid (Raicu et al., 1973). 10 fields were microscopically analyzed on each slide. A Nikon Eclipse 600 light microscope was used for this analysis. Photos were taken with a Nikon Cool Pix 950 digital camera, 1600×1200 dpi.

The cytogenetic indicators were calculated according to the following formulas: Mitotic index (MI) (\%) =
TDC $\times 100 /$ TC; prophase index $($ PI\% $)=$ prophase cells $\times 100 /$ TDC; metaphase index $($ MeI\%) = metaphase cells $\times 100 /$ TDC; anaphase index $($ AI\% $)=$ anaphase cells $\times$ 100/TDC; telophase index $($ TI\% $)=$ telophase cells $\times 100 /$ TDC, where TDC: total dividing cells and TC: total cells (dividing and non-dividing).

The rate of ana-telophase chromosome aberrations (A$\left.T_{C A} \%\right)$ and the rate of metaphase abnormalities ( $\left.M_{a b n} \%\right)$ were also calculated in relation to the number of cells in mitosis: $\mathrm{A}-\mathrm{T}_{\mathrm{CA}} \%=\mathrm{A}-\mathrm{T}_{\mathrm{CA}} \times 100 / \mathrm{TDC}$, and $\mathrm{M}_{\mathrm{abn}} \%=\mathrm{M}_{\mathrm{abn}}$ $\times 100 /$ TDC.

The data were expressed as mean \pm standard error of the means for all groups of investigated parameters. The Microsoft Office Excel 2003 software of Windows XP operating system was used to calculate and graphically represent the statistical parameters.

\section{Results and discussion}

\section{Mitotic index and frequency of cell division stages}

In Patra's classification (2004) based on the severity of the effects on mitosis, the heavy metals are grouped in three classes, $\mathrm{Zn}$ being included in the class with marked impact on cell division, together with $\mathrm{Al}, \mathrm{Mn}, \mathrm{Fe}, \mathrm{Se}, \mathrm{Sr}$, $\mathrm{Sb}, \mathrm{Ca}$, and $\mathrm{Ti}$. Contrary to the opinions expressed in other studies (Jain et al., 2010; Powell et al., 1986), in this research $\mathrm{Zn}$ augmented MI as compared to the control, the stimulatory effect resulting in increases of approximately $23-57 \%$ in $\mathrm{Zn}$ acetate treated variants, and $10-80 \%$ for Zn sulphate (Tab. 1; Fig. 1). In Zn sulphate treated variants, the highest average value of MI was registered for the $100 \mu \mathrm{M}$ concentration. From this point, a progressive MI decrease occurs in variants exposed to 250 and $500 \mu \mathrm{M}$ concentrations, but the level still remains over the control. In $\mathrm{Zn}$ acetate treated variants, a descending trend from 10 $\mu \mathrm{M}$ to $250 \mu \mathrm{M}$ was noticed, followed by a MI increase at the maximum tested concentration. Whereas some previous studies (El-Ghamery et al., 2003; Shaymurat et al., 2012) revealed a dose-dependent inhibition of $\mathrm{MI}$ in $\mathrm{Zn}$ treatments, Somesh et al. (2005) confirmed the mitodepressive potential of $\mathrm{Zn}$ acetate and $\mathrm{Zn}$ sulphate only at concentrations over $500 \mathrm{ppm}$, while the lower concentrations, comparable with those tested in our study, stimulated MI.

As concerns the frequency of mitotic phases, the decreasing order of the division stages was generally the following: $\mathrm{PI} \%>\mathrm{MeI} \%>\mathrm{TI} \%>\mathrm{AI} \%$. Except for 500 $\mu \mathrm{M} \mathrm{Zn}$ sulphate and $250 \mu \mathrm{M} \mathrm{Zn}$ acetate, where the average PI\% is close to the control, in the other variants the number of prophases exceeds the control. The MI increase is the result of the accumulation of prophases and metaphases, or of telophases, as it happens in $10 \mu \mathrm{M} Z n$ acetate (Tab. 1; Fig. 2). Alterations in the frequency of mitotic phases as compared to the control have also been reported in wheat and Nigella sativa after Zn supply (El-Ghamery et al., 2003). 
152

Tab. 1. Behaviour of the cytogenetic parameters in barley root tip meristems, after seed short term exposure to different concentrations of zinc sulphate and zinc acetate

\begin{tabular}{|c|c|c|c|c|c|c|c|c|}
\hline \multirow{2}{*}{\multicolumn{2}{|c|}{ Variant }} & \multicolumn{2}{|c|}{ Analyzed cells } & \multirow{2}{*}{ MI (\%)* } & \multirow{2}{*}{ PI\% } & \multirow{2}{*}{ MeI\% } & \multirow{2}{*}{$\mathrm{AI} \%$} & \multirow{2}{*}{$\mathrm{TI} \%$} \\
\hline & & Number & $\mathrm{x} \pm \mathrm{SE}^{*}$ & & & & & \\
\hline \multirow{5}{*}{ Zinc sulphate } & $0 \mu \mathrm{M}$ & 9694 & $1938.8 \pm 246.46$ & $3.88 \pm 0.18$ & 29.27 & 27.42 & 20.84 & 22.45 \\
\hline & $10 \mu \mathrm{M}$ & 6732 & $1346.4 \pm 29.51$ & $4.26 \pm 0.38$ & 35.54 & 25.73 & 17.77 & 20.93 \\
\hline & $100 \mu \mathrm{M}$ & 4153 & $830.6 \pm 49.82$ & $7.04 \pm 0.52$ & 34.73 & 21.12 & 20.38 & 23.73 \\
\hline & $250 \mu \mathrm{M}$ & 7864 & $1006.4 \pm 51.00$ & $5.16 \pm 0.38$ & 36.67 & 28.39 & 18.31 & 16.59 \\
\hline & $500 \mu \mathrm{M}$ & 6138 & $1227.6 \pm 126.34$ & $4.42 \pm 0.42$ & 28.22 & 31.35 & 18.84 & 21.57 \\
\hline \multirow{5}{*}{ Zinc acetate } & $0 \mu \mathrm{M}$ & 9694 & $1938.8 \pm 246.46$ & $3.88 \pm 0.18$ & 29.27 & 27.42 & 20.84 & 22.45 \\
\hline & $10 \mu \mathrm{M}$ & 6100 & $1220.6 \pm 100.20$ & $5.90 \pm 0.54$ & 30.27 & 26.15 & 17.24 & 26.32 \\
\hline & $100 \mu \mathrm{M}$ & 5202 & $1040.4 \pm 49.55$ & $5.55 \pm 0.24$ & 32.67 & 30.12 & 18.46 & 18.73 \\
\hline & $250 \mu \mathrm{M}$ & 5677 & $1135.4 \pm 32.11$ & $4.77 \pm 0.35$ & 28.62 & 29.07 & 19.77 & 22.54 \\
\hline & $500 \mu \mathrm{M}$ & 5750 & $1150.0 \pm 54.29$ & $6.08 \pm 0.62$ & 34.97 & 24.00 & 18.36 & 22.67 \\
\hline
\end{tabular}

*mean \pm standard error of the means; $\mathrm{MI}=$ mitotic index; PI\% prophase index; $\mathrm{MeI} \%=$ metaphase index; $\mathrm{AI} \%=$ anaphase index; $\mathrm{TI} \%=$ telophase index $(\mathrm{mitotic}$ phases values were calculated considering mitotic index as $100 \%$ )

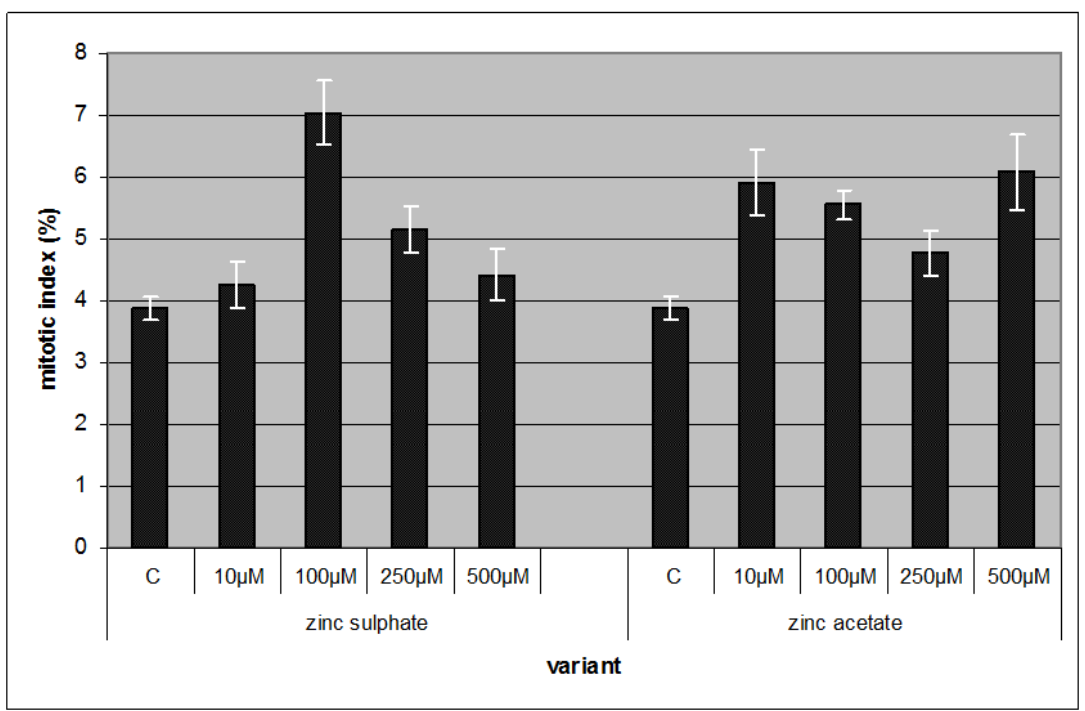

Fig. 1. Mitotic index in barley root meristems, after zinc treatment (the bars represent the standard errors of the means)

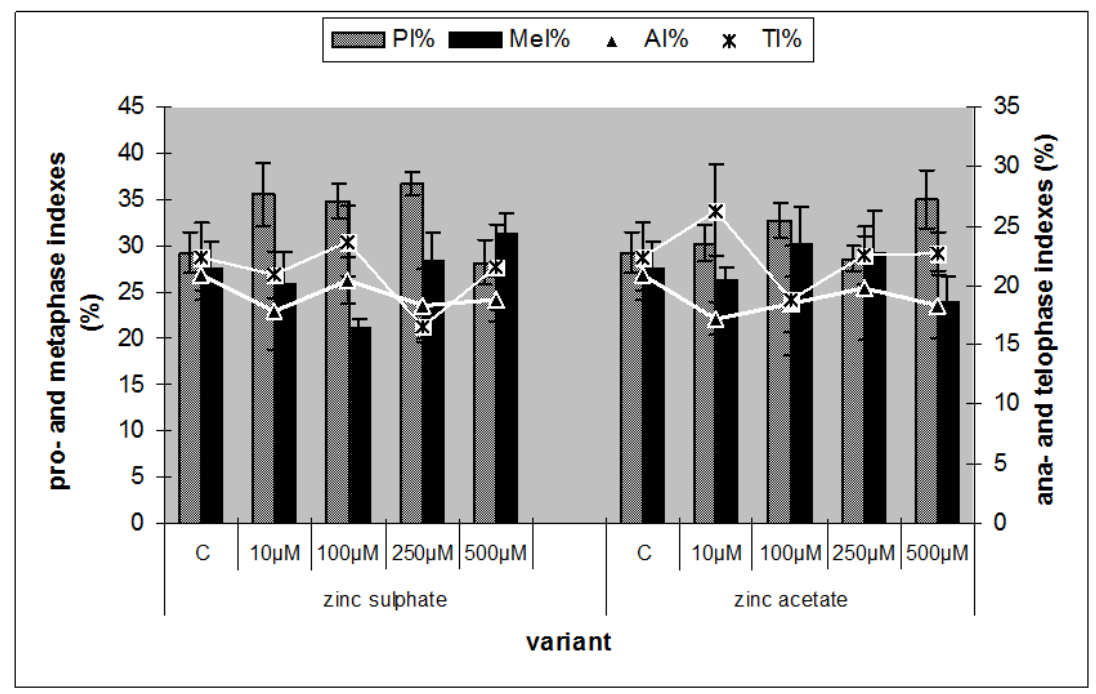

Fig. 2. Frequency of the mitotic stages in barley root meristems, after zinc treatment (the bars represent the standard errors of the means) 
Frequency of abnormal metaphases

$\mathrm{M}_{\mathrm{abn}} \%$ is much higher as compared to $\mathrm{A}-\mathrm{T}_{\mathrm{CA}} \%$. Hence, $\mathrm{Zn}$ sulphate determined $5.4-8.3$ times more abnormal metaphases, whereas $\mathrm{Zn}$ acetate induced 7.0 - 10.0 times more metaphase disturbances, as compared to the control (Fig. 3). Concerning disturbance categories, C-metaphases, which indicate an effect of zinc similar to that induced by colchicine, are numerically preponderant in all Zn-treated variants (Fig. 4).

Metaphase stickiness (Fig. 6h) occurred within a 3 to $11 \%$ variation range (the highest value was observed for $250 \mu \mathrm{M} \mathrm{Zn}$ acetate). In all $\mathrm{Zn}$-treated variants, chromosomes expulsed from equatorial plates have been detected. Their level was 3.0 - 5.5 times higher than the control in Zn sulphate treated variants, and 3.5 - 7.0 times higher for $\mathrm{Zn}$ acetate (Fig. 4).

The high values of C-metaphases, scattered and expelled chromosomes (Fig. 6d, e, i) prove the aneugenic action of $\mathrm{Zn}$ compounds, probably due to the perturbation of calmodulin, a small $\mathrm{Ca}^{2+}$-binding protein involved in the chromosome moving by the control of microtubule polymerization/depolymerization (Zou et al., 2006).

\section{Frequency of ana-telophase chromosome aberrations}

All concentrations of $\mathrm{Zn}$-containing compounds induced important increases of the rate of ana-telophase chromosome aberrations (Fig. 3). A- $\mathrm{T}_{\mathrm{CA}} \%$ in root tip meristems of $\mathrm{Zn}$-treated variants of barley exceeded by $2-3$ times the control, in a progressive manner up to $250 \mu \mathrm{M}$, in $\mathrm{Zn}$ sulphate treated variants, and up to $500 \mu \mathrm{M}$, in $\mathrm{Zn}$ acetate treated variants.

Chromosome bridges (Fig. 5 and 6c) surpass by 2.2 2.6 times the control in $\mathrm{Zn}$ sulphate treatments, and by 1.6 - 3.3 times in $\mathrm{Zn}$ acetate treated variants. The highest levels were encountered in 250 and $500 \mu \mathrm{M} \mathrm{Zn}$ acetate.

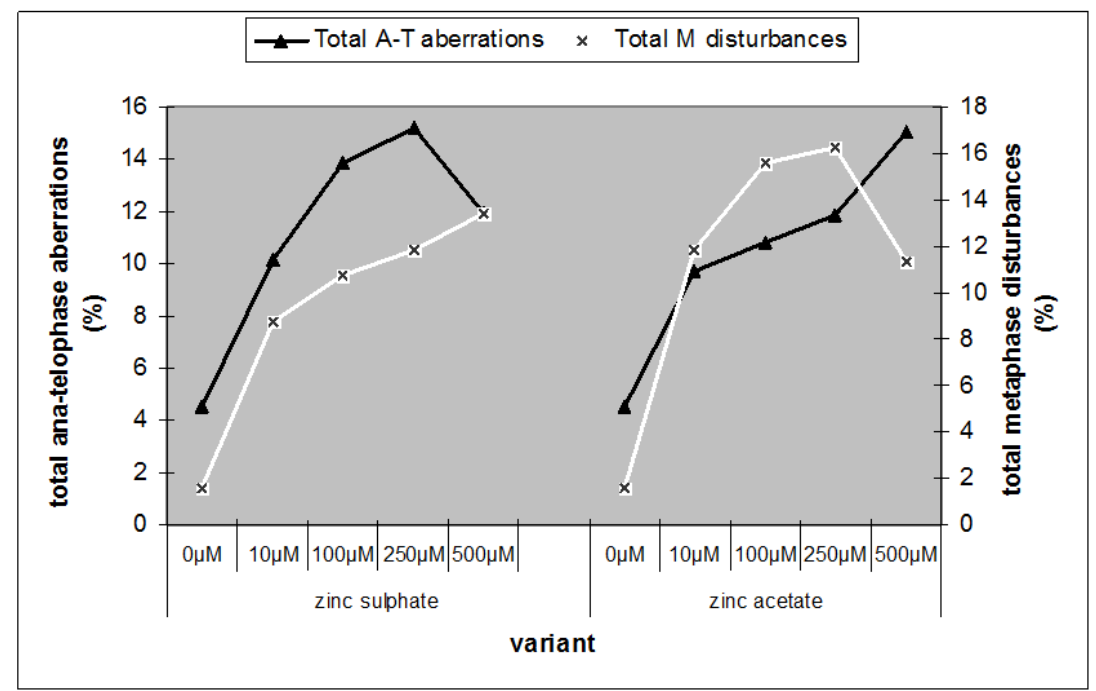

Fig. 3. Incidence of the ana-telophase aberrations and of metaphase abnormalities induced by zinc in barley root meristems

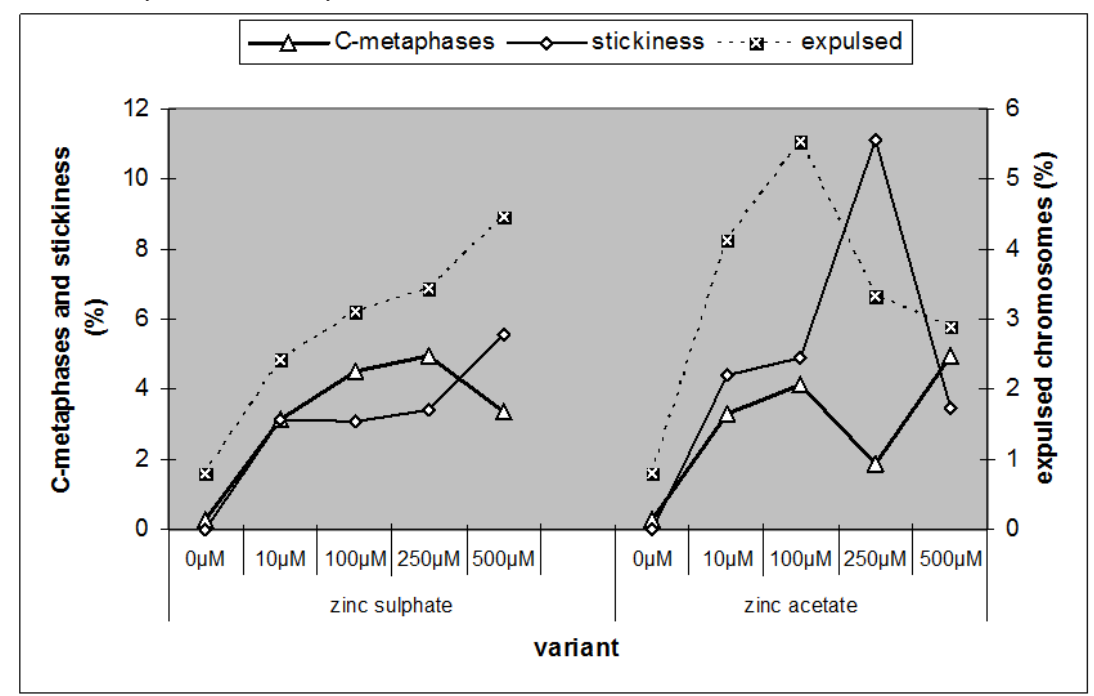

Fig. 4. Incidence of the main categories of zinc-induced metaphase disorders in barley root meristems 
154

Complex aberrations (multipolarity + bridges + expelled chromosomes + laggards; bridges + expelled chromosomes etc.) show high frequency (Fig. 5, 6f). They are often accompanied by major changes in the phenotype expression. In $\mathrm{Zn}$ acetate treatments, their levels surpassed by 2.5 - 5.0 times the control, and for $\mathrm{Zn}$ sulphate the complex aberrations were $1.2-4.2$ times more numerous as compared to the control. Instead, the occurrence of laggards was 5 - 7 fold higher than the control in $\mathrm{Zn}$ sulphate exposures, while for $\mathrm{Zn}$ acetate their frequency varied between 1.16 and $1.64 \%$ (2 - 3-fold increases as compared to the control) (Fig. 5). The extent of multipolarity and expelled chromosomes was smaller.
$250 \mu \mathrm{M}$ and $500 \mu \mathrm{M} \mathrm{Zn}$ acetate induced lysis of chromatin material (Fig. 6g) and stickiness in all stages of mitotic division (Fig. 6h). Stickiness indicates an increased toxicity of the tested chemicals the effects of which - usually irreversible - result in cell death. The maximum $\mathrm{Zn}$ acetate concentration caused nuclear material fragmentation or determined the occurrence of different nuclear shapes (Fig. 6b). The presence of micronuclei was sporadically detected in $500 \mu \mathrm{M} \mathrm{Zn}$ sulphate; they can be acentric fragments (clastogenic response) or can result from deficient function of mitotic spindle (aneugenic response). Micronuclei were also reported at high $\mathrm{Zn}^{2+}$ doses in Vicia faba (Kumari et al., 2012).

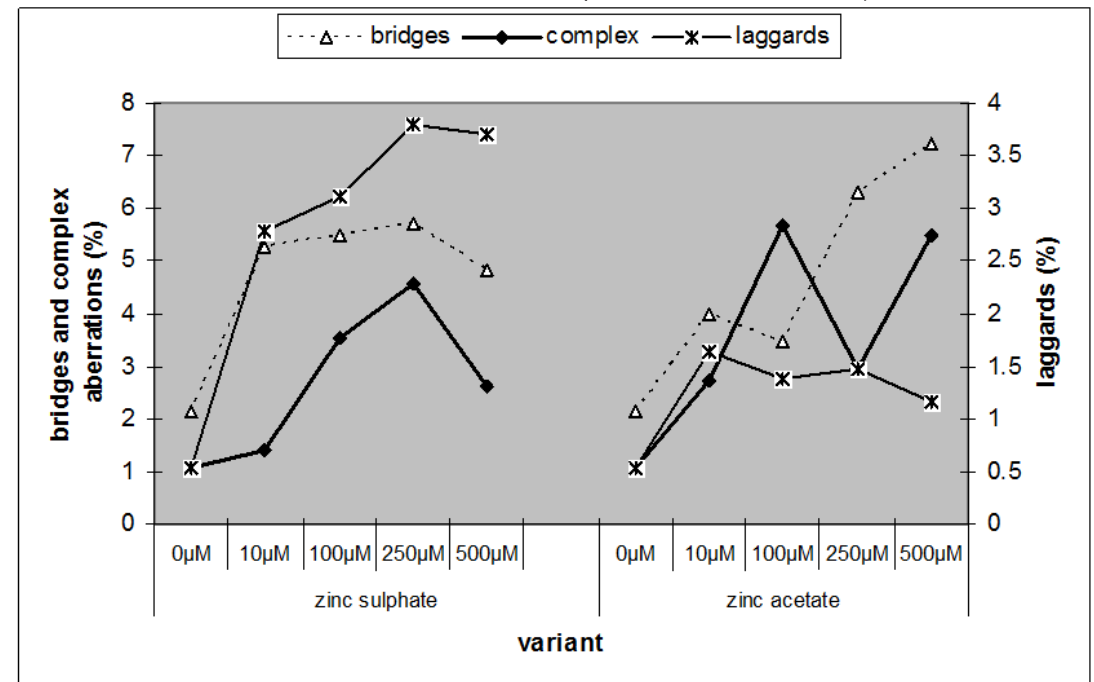

Fig. 5. Frequency of the main categories of zinc-induced ana-telophase chromosome aberrations in barley root meristems

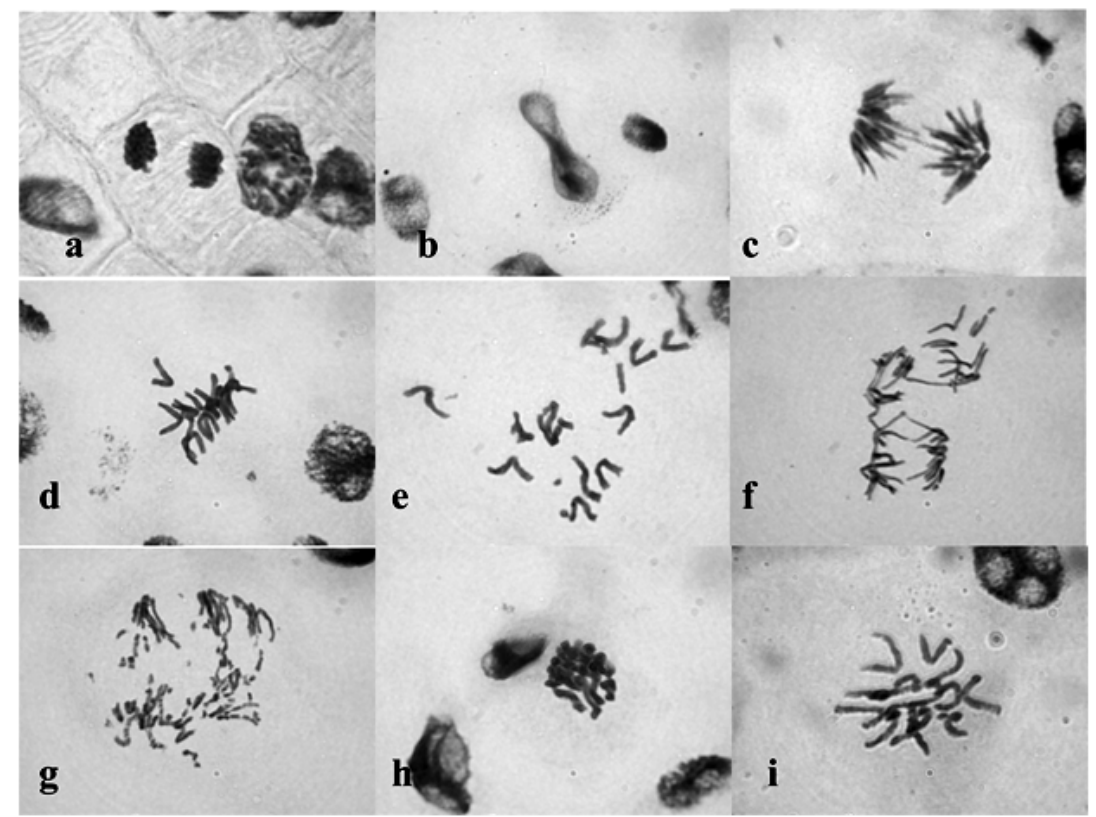

Fig. 6. Types of zinc-induced disturbances. a. polar deviation - $500 \mu \mathrm{M} Z \mathrm{Zn}$ sulphate; b. atypical nucleus in interphase $-250 \mu \mathrm{M} \mathrm{Zn}$ sulphate; c. bridge - $250 \mu \mathrm{M} Z \mathrm{Zn}$ acetate; $\mathrm{d}$. metaphase with expulsed chromosome - $10 \mu \mathrm{M} \mathrm{Zn}$ sulphate; e. scattered metaphase chromosomes - $500 \mu \mathrm{M} Z \mathrm{Zn}$ sulphate; f. complex aberration - $250 \mu \mathrm{M} \mathrm{Zn}$ sulphate; g. chromatin lysis in anaphase - $10 \mu \mathrm{M} \mathrm{Zn}$ sulphate; h. stickiness - $500 \mu \mathrm{M}$ Zn sulphate; i. C-metaphase - $500 \mu \mathrm{M} \mathrm{Zn}$ acetate 
Contrasting and inconclusive data on the genotoxicity of $\mathrm{Zn}$ compounds are available in literature. The observations recorded on several herbaceous and woody species showed differentiated responses, depending on the concentration range, exposure duration, plant species, class of $\mathrm{Zn}$ compounds, and treatment with unary or binary solutions (Ince et al., 1999; Marcato-Romain et al., 2009; Patra et al., 2004; Steinkellner et al., 1998), but also on the number of somatic and metacentric chromosomes or on the length of the diploid complement (Ma et al., 1995). Some reports state that high $\mathrm{Zn}$ concentrations are not strongly genotoxic (Codina et al., 2000; Gómez-Arroyo et al. 2001; Marcato-Romain et al., 2009). The aneugenic and clastogenic action of $\mathrm{Zn}$ was also evidenced in other species like wheat, black cumin, onion, sugarcane (El-Ghamery et al., 2003; Jain et al., 2010; Shaymurat et al., 2012; Somesh et al., 2005), but a connection between $\mathrm{Zn}$ concentration and aberration frequency was not always noticed.

The relatively wide range of rates of metaphase abnormalities and ana-telophase chromosome aberrations supports the genotoxic potential of zinc. The high level of chromosome aberrations offers indications on their interference with nucleic acids and on the clastogenic potential of $\mathrm{Zn}$, while the disturbances implying the mitotic spindle prove its aneugenic action.

\section{Conclusions}

Although $\mathrm{Zn}$ holds one of the last places regarding cyto- and genotoxicity, the extent of the clastogenic and aneugenic responses to $\mathrm{Zn}$ action in the investigated barley genotypes is significant enough to conclude that it is necessary to extend the assessment of the genetic impact of $\mathrm{Zn}$, in order to gain thorough knowledge not only of the induced chromosome damage but also of the consequences on some phenotype traits of economic interest. These results can be used to improve the management of heavy metal-containing compounds, with positive repercussions on habitats and the health of living systems.

\section{Acknowledgements}

This study was supported by the PN-09-36-301/20092011 - BIODIV project, National Program for Research and Development, Romania.

\section{References}

Banu BS, Devi KD, Mahboob M, Jamil K (2001). In vivo genotoxic effect of zinc sulfate in mouse peripheral blood leukocytes using comet assay. Drug Chem Toxicol 24(1):63-73.

Broadley MR, White PJ, Hammond JP, Zelko I, Lu A (2007). Zinc in plants. New Phytol 173:677-702.

Codina JC, Cazorla FM, Perez-Garcia A, De Vicente A (2000). Heavy metal toxicity and genotoxicity in water and sewage determined by microbiological methods. Environ Toxicol Chem 19(6):1552-1558.
Davis RD, Beckett PHT, Wollan E (1978). Critical levels of twenty potentially toxic elements in young spring barley. Plant Soil 49:395-408.

Deknudt G, Deminatti M (1978). Chromosome studies in human lymphocytes after in vitro exposure to metal salts. Toxicology 10:67-75.

El-Ghamery AA, El-Kholy A, El-Yousser A (2003). Evaluation of cytological effects of $\mathrm{Zn}^{2+}$ in relation to germination and root growth of Nigella sativa L. and Triticum aestivum L. Mutat Res-Gen Tox En 537(1):29-41.

Gamborg OL, Wetter LR (1975). Plant tissue culture methods. National Research Council, Prairie Regional Laboratory, Saskatoon, Canada, 110 p.

Gómez-Arroyo S, Cortés-Eslava J, Bedolla-Cansino RM, Villalobos-Pietrini R, Calderón-Segura ME, Ramírez-Delgado Y (2001). Sister chromatid exchanges induced by heavy metals in Vicia faba. Biol Plant 44:591-594.

Ince NH, Dirilgen N, Apikyan IG, Tezcanli G, Ustün B (1999). Assessment of toxic interactions of heavy metals in binary mixtures: a statistical approach. Arch Environ Con Tox 36:365-372.

Jain R, Srivastava S, Solomon S, Shrivastava AK, Chandra A (2010). Impact of excess zinc on growth parameters, cell division, nutrient accumulation, photosynthetic pigments and oxidative stress of sugarcane (Saccharum spp.). Acta Physiol Plant 32:979-986.

Kabata-Pendias A, Pendias H (2001). Trace Elements in Soils and Plants. 3rd ed. CRC Press, 413 p.

Kowalska-Wochna E, Moniuszko-Jakoniuk J, Kulikowska E, Miniuk K (1988). The effect of orally applied aqueous solutions of lead and zinc on chromosome aberrations and induction of sister chromatid exchanges in the rat (Rattus sp.). Genet Pol 29(2):181-189.

Kumari N, Abha A, Jha AM (2012) Genotoxicity testing of food additives by employing Vicia MN assay. Journal of Phytology 4(5):42-45.

Lumen BO (2008). Lunasin: a novel cancer preventive seed peptide that modifies chromatin. J AOAC Int 91(4):932-935.

Ma TH, Xu Z, Xu C, McConnell H, Rabago EV, Arreola GA, Zhang H (1995). The improved Allium/Vicia root tip micronucleus assay for clastogenicity of environmental pollutants. Mutat Res 334(2):185-195.

Macnicol RD, Beckett PHT (1985). Critical tissue concentrations of potentially toxic elements. Plant Soil 85(1):107129.

Marcato-Romain CE, Pinelli E, Pourrut B, Silvestre J, Guiresse $M$ (2009). Assessment of the genotoxicity of $\mathrm{Cu}$ and $\mathrm{Zn}$ in raw and anaerobically digested slurry with the Vicia faba micronucleus test. Mutat Res-Gen Tox En 672(2):113-118.

Päivöke AEA (2003). Responses of Pisum sativum to soil arsenate, lead and zinc: a greenhouse study of mineral elements, phytase activity, ATP and chlorophylls. Univ. Helsinki 1-84. 
156

Paschke MW, Perry LG, Redente EF (2006). Zinc toxicity thresholds for reclamation forb species. Water Air Soil Poll 170:317-330.

Patra M, Bhowmik N, Bandopadhyay B, Sharma A (2004). Comparison of mercury, lead and arsenic with respect to genotoxic effects on plant systems and the development of genetic tolerance. Environ Exp Bot 52(3):199-223.

Powell MJ, Davies MS, Francis D (1986). The influence of zinc on the cell cycle in the root meristem of a zinc-tolerant and a non-tolerant cultivar of Festuca rubra L. New Phytol 102:419-428.

Raicu P, Anghel I, Popescu C, Duma D, Nicolaescu M, Taisescu E (1973). Lucrari practice de genetica. Centrul de Multiplicare al Universitatii din Bucuresti, 430 p.

Romania Sanitation Coutry Profile (2004). National Sustainable Development Report. Government of Romania.

Salama ZA, El Fouly M (2008). Evaluation of the efficiency of some Egyptian wheat Triticum aestivum L. cultivars to $\mathrm{Zn}$ deficiency through peroxidase activity and protein profile techniques. Not Bot Horti Agrobo 36(2):42-46.
Shaymurat T, Gu J, Xu C, Yang Z, Zhao Q, Liu Y, Liu Y (2012). Phytotoxic and genotoxic effects of $\mathrm{ZnO}$ nanoparticles on garlic (Allium sativum L.): A morphological study. Nanotoxicology 6(3):241-248.

Somesh Y, Kumar SH, Meenu S (2005). Toxic effects of some heavy metals using plant chromosomal aberrations assays. Vegetos 18(1-2):67-77.

Steinkellner H, Mun-Sik K, Helma C, Ecker S, Ma TH, Horak O, Kundi M, Knasmüller S (1998). Genotoxic effects of heavy metals: Comparative investigation with plant bioassays. Environ Mol Mutagen 31(2):183-191.

Tewari RK, Kumar P, Sharma PN (2008). Morphology and physiology of zinc-stressed mulberry plants. J Plant Nutr Soil Sci 171:286-294.

Thompson ED, McDermott JA, Zerkle TB, Skare JA, Evans BLB, Cody DB (1989). Genotoxicity of zinc in 4 short-term mutagenicity assays. Mutat Res 223(3):267-272.

Zou JH, Wang M, Jiang WS, Liu DH (2006). Effects of hexavalent chromium (VI) on root growth and cell division in root tip cells of Amaranthus viridis L. Pak J Bot 38(3):673-681. 